J. Lake Sci. (湖泊科学), 2020, 32(4): 1088-1099

DOI 10. 18307/2020. 0417

(c) 2020 by Journal of Lake Sciences

\title{
九寨沟国家级自然保护区长海夏季浮游植物群落结构及生态评价”
}

\author{
邢冰伟 ${ }^{1}$, 徐季雄 ${ }^{1}$, 曹 玥 $^{1}$, 邓贵平 ${ }^{2,3}$, 庞婉婷 ${ }^{* * *}$, 王全喜 ${ }^{1}$ \\ (1: 上海师范大学生命科学学院, 上海 200234) \\ (2: 成都理工大学旅游与城乡规划学院, 成都 610059) \\ (3:九寨沟国家级自然保护区管理局,阿坝 623402)
}

\begin{abstract}
摘 要: 高山湖泊对于全球气候变化及人类影响是一个极为敏感的参照系统. 九寨沟国家级自然保护区长海作为一个独 特的高山湖泊, 研究其浮游植物群落结构及其与环境的关系, 评估其水质现状及影响因素, 有着重要的意义. 本文于 2014 年 7 月对长海浮游植物群落结构进行了研究. 全湖共布设 12 个采样点, 并在中心采样点进行了垂直分层采样. 本次调查 共发现浮游植物 6 门 38 属 63 种, 平均丰度为 $6.98 \times 10^{5} \mathrm{cells} / \mathrm{L}$, 平均生物量为 $0.31 \mathrm{mg} / \mathrm{L}$. 浮游植物的水平分布差异不大; 在垂直分布上, 浮游植物的丰度从表层 $0.5 \mathrm{~m}$ 至水下 $50 \mathrm{~m}$ 呈现先增加后减少的趋势, 在 $20 \mathrm{~m}$ 水深处达到最大. 长海浮游 植物的优势种是长海小环藻 (Cyclotella changhai) 和飞燕角甲藻 (Ceratium hirundinella), 长海小环藻数量较多, 飞燕角甲 藻生物量较大. 长海浮游植物多样性指数较低, 综合各类水质评价方法, 可以得出九寨沟长海处于贫一中营养状态.
\end{abstract}

关键词: 九寨沟国家级自然保护区; 高山湖泊;浮游植物;群落结构;生态评价; 长海

\section{Phytoplankton community structure and ecological evaluation in summer, Lake Changhai of Jiuzhaigou National Nature Reserve*}

\author{
XING Bingwei ${ }^{1}$, XU Jixiong $^{1}$, CAO Yue ${ }^{1}$, DENG Guiping ${ }^{2,3}$, PANG Wanting ${ }^{1 * *} \&$ WANG Quanxi \\ (1: College of Life Sciences, Shanghai Normal University, Shanghai 200234, P.R.China) \\ (2: Tourism and Urban-Rural Planning College of Chengdu University of Technology, Chengdu 610059, P.R.China) \\ (3: Jiuzhaigou National Nature Reserve Administraion, Aba 623402, P.R.China)
}

Abstract: Alpine lakes are sensitive reference systems of global climatic change and other human impacts. As a unique alpine lake, Lake Changhai of Jiuzhaigou National Nature Reserve has important significance in studying its phytoplankton community structure and it's relationship with the environment. It is also important to assess the status of water quality and its influencing factors. In order to understand the phytoplankton community structure, 12 sites were selected to collect phytoplankton samples in July 2014. Vertical stratified sampling was performed at the central sampling point. The 63 taxa of phytoplankton belonging to 38 genera in 6 phyla were identified, the average phytoplankton abundance was $6.98 \times 10^{5}$ cells/ $\mathrm{L}$, the average phytoplankton biomass was $0.31 \mathrm{mg} / \mathrm{L}$. There is no significant difference in the horizontal distribution of the phytoplankton. In the vertical distribution, the abundance of phytoplankton increased first and then decreased from $0.5 \mathrm{~m}$ to $50 \mathrm{~m}$, and reached the maximum at the depth of $20 \mathrm{~m}$. Cyclotella changhai and Ceratium hirundinella were the dominant species. Cyclotella changhai were higher amounts, Ceratium hirundinella were higher biomass. The phytoplankton diversity index was low. Synthesizing all kinds of methods to evaluate water quality, Lake Changhai was in a poor-medium pollution state.

Keywords: Jiuzhaigou National Nature Reserve; alpine lake; phytoplankton; community structure; ecological evaluation; Lake Changhai

九寨沟国家级自然保护区是国家首批 5A 级风景区, 于 1992 年被联合国教科文组织列入世界自然遗产

* 2019-10-22 收稿; 2019-11-19 收修改稿.

国家国际科技合作专项 (2013DFR90670) 资助.

** 通信作者; E-mail:pangwt@ shnu.edu.cn. 
名录, 1997 年被纳人世界人与生物圈保护区网络. 九寨沟的旅游业发展迅速, 游客人数从 1984 年的不足 3 万人次到 2015 年激增到超过 5 百万人次 ${ }^{[1]}$. 游客人数的快速增长, 使得水体中氮、磷浓度增加, 湖泊水体富 营养化 ${ }^{[2]}$, 使九寨沟的生态系统变得异常复杂. 长海 $\left(33^{\circ} 0^{\prime} 75^{\prime \prime} \sim 33^{\circ} 4^{\prime} 70^{\prime \prime} \mathrm{N}, 103^{\circ} 92^{\prime} 97^{\prime \prime} \sim 103^{\circ} 94^{\prime} 38^{\prime \prime} \mathrm{E}\right)$ 位于九 寨沟国家级自然保护区则查洼沟的中部, 海拔 $3060 \mathrm{~m}$, 面积 $0.9957 \mathrm{~km}^{2}$, 平均水深 $44.57 \mathrm{~m}$, 是九寨沟湖面最 宽、水深最深的湖泊, 湖泊最深处达百余米, 呈 $\mathrm{S}$ 行展布. 丰水期的长海容积达 $4600 \times 10^{4} \mathrm{~m}^{3}$, 比树正沟和日 则沟湖泊容积之和的 3 倍还多. 其水源补给来自于雨水、高山冰雪融化、降雨和地下水. 而水的排泄除了少 部分会通过地表径流流向下游以外, 主要通过地下岩通道排向另一侧的日则沟. 根据同位素示踪技术, 长海 水沿溶岩通道向日则沟箭竹海一天鹅海段渗透,丰水期量占箭竹海径流总量的 $21 \%$, 枯水期为 $28 \%$, 绝对渗 透量稳定, 无季节变化 ${ }^{[3]}$. 长海是九寨沟内湖泊群重要的天然调节水库 ${ }^{[4]}$. 因长海的水文地质条件, 使其成 为独特的高山湖泊生态系统.

高山湖泊对于全球气候变化及人类影响是一个极为敏感的参照系统 ${ }^{[5-6]}$. 由于其处于特殊的地理位置和 较为极端的环境条件, 如低温、强辐射, 大部分缓冲能力较低, 营养水平低, 因此, 相对于其他湖泊而言, 高山湖 泊的水生态系统相对简单, 对于环境的响应更快、更敏感. 即使很小的变化也能显著影响高山湖泊的理化性 质, 从而引起生物组成和群落结构的变化 ${ }^{[6-8]}$. 浮游植物在水生生态系统中占有重要地位, 对水域生态系统的 物质循环、能量流动及维持水域生态系统平衡方面都起着非常重要的作用 ${ }^{[9]}$. 因此研究高山湖泊浮游植物群 落结构对揭示湖泊生态系统功能的变化, 预测生态系统对当前以及未来环境变化的响应有着重要意义.

最早研究高山高寒湖泊浮游生物可以追溯到 19 世纪末 20 世纪初, 主要是研究浮游动物的种类组成和 地理分布 ${ }^{[10-13]}$, 此后有关生命周期、浮游生物垂直迁移等生态学问题引起了研究者的关注 ${ }^{[14-15]}$. 自 1950 年 以来, 学者们研究了在厚冰层下浮游植物生存的机制及调节垂直分布的季节性变化 ${ }^{[16-18]}$, 金藻和隐藻等几 种藻类的混合营养上 ${ }^{[19-22]}$, 氮、磷的变化对湖泊有很大的生态影响等方面的问题 ${ }^{[23-26]}$, 取得了一些重要的研 究结果. 我国对于高山湖泊的研究较晚, 云宝琛等调查了长白山天池的浮游植物群落结构, 分析了其结构组 成 ${ }^{[27]}$, 马晓东等分析了新疆柴窝堡湖浮游植物的群落结构特征 ${ }^{[28]}$, 我国高山湖泊众多, 但相关研究相对较 弱. 本文于 2014 年 7 月对长海浮游植物群落组成进行研究, 探讨影响长海浮游植物水平分布和垂直分布的 成因, 为高山湖泊生态系统的研究提供资料.

\section{1 材料与方法}

\section{1 采样时间和样点设置}

于 2014 年 7 月,在长海全湖共布设 12 个样点. 在湖中心最 深的 $\mathrm{s} 8$ 点 $(80 \mathrm{~m})$ 自表层沿垂直方向布设 9 个分层 $(0.5 、 5 、 10$ 、 $15 、 20 、 25 、 30 、 40 、 50 \mathrm{~m})$ 进行采样, 见图 1 .

\section{2 样品采集与处理}

浮游植物定性、定量样品的采集及计数方法根据《淡水浮游生 物研究方法》等相关文献 ${ }^{[29-30]}$. 浮游植物鉴定采用经典文献 ${ }^{[31-36]}$. 垂直样品用 $1 \mathrm{~L}$ 采水器分别在 $0.5 \mathrm{~m}(\mathrm{~s} 8-1) 、 5 \mathrm{~m}(\mathrm{~s} 8-2) 、 10 \mathrm{~m}(\mathrm{~s} 8-$ 3)、 $15 \mathrm{~m}(\mathrm{~s} 8-4) 、 20 \mathrm{~m}(\mathrm{~s} 8-5) 、 25 \mathrm{~m}(\mathrm{~s} 8-6) 、 30 \mathrm{~m}(\mathrm{~s} 8-7) 、 40 \mathrm{~m}(\mathrm{~s} 8-$ 8)、 $50 \mathrm{~m}(\mathrm{~s} 8-9)$ 处采集 2 次,之后使用常规方法处理. 同步采集水 样测水质. 其中水温、 $\mathrm{pH}$ 值、溶解氧 ( DO) 等指标用 YSI 水质分析 仪现场测定; 总氮 $(\mathrm{TN}) 、$ 氨氮、总磷 $(\mathrm{TP}) 、$ 化学需氧量参照《湖泊 富营养化调查规范》在实验室进行测定 ${ }^{[37]}$.

\section{3 数据统计与分析}

在 Microsoft Excel 2010 中完成主要数据整理及分析; Surfer 12 软件完成对浮游植物水平分布等值线图绘制; C2 软件完成部 分浮游植物丰度和生物量变化的柱状图绘制.

优势种计算采用了 Mcnaughton 优势度 $(Y)$, 公式为:

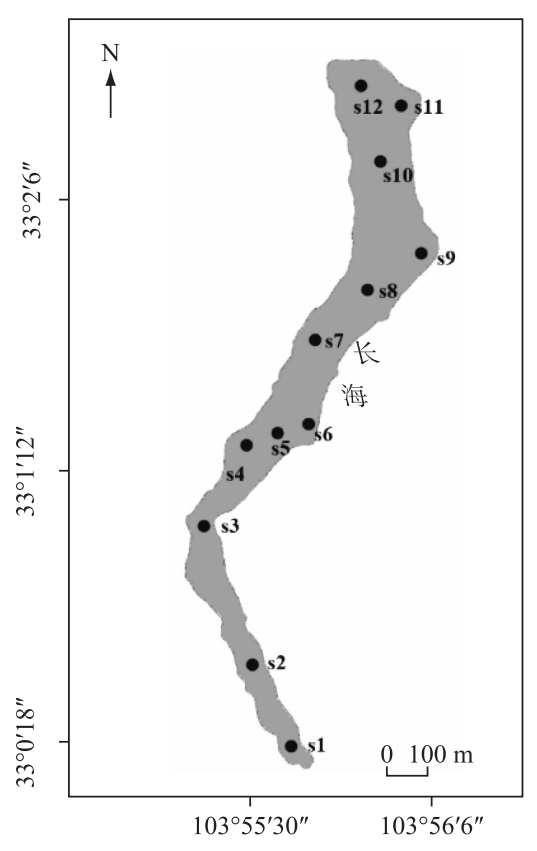

图 1 长海采样点示意

Fig. 1 Location of the sampling sites in Lake Changhai 


$$
Y=f_{i}\left(n_{i} / N\right)
$$

式中, $n_{i} / N$ 为第 $i$ 种个体数 $n_{i}$ 与总浮游植物个体数 $N$ 的比值; $f_{i}$ 为第 $i$ 种在各点位的出现频率.

也可根据 Kikvidze 提出的优势种数目计算的方法:

$$
A=1 / \sum_{1}^{S} V_{i}^{2}
$$

式中, $V_{i}$ 是第 $i$ 种的相对丰度; $S$ 为群落中的物种数; $A$ 为该群落中优势种个数.

Shannon-Wiener 多样性指数 $\left(H^{\prime}\right)$ 计算公式:

$$
H^{\prime}=-\sum\left(n_{i} / N\right) \log _{2}\left(n_{i} / N\right)
$$

Margalef 多样性指数 $(d)$ 计算公式为:

$$
d=(S-1) / \ln N
$$

Pielou 均匀度指数 $(e)$ 计算公式 ${ }^{[38]}$ 为:

$$
e=H^{\prime} / \lg S
$$

\section{2 结果与分析}

\section{1 长海浮游植物的水平分布}

本次调查共发现浮游植物 63 种, 隶属 6 门 38 属, 其中硅藻门 26 属 51 种, 绿藻门 4 属 4 种, 甲藻门 3 属 3 种, 金藻门 2 属 2 种, 隐藻门 2 属 2 种, 蓝藻门 1 属 1 种. 在长海浮游植物种类组成中, 硅藻门种类数最多, 占长海浮游植物种类数的 $81 \%$, 其他门浮游植物种类数比例较小. 由图 2 可知, 各点位浮游植物种类数变化 在 $15 \sim 26$ 种之间, 各位点种类组成变化不大, 硅藻门在各点位种类组成中仍占据最大比例, 占比达到 $47 \% \sim 73 \%$.

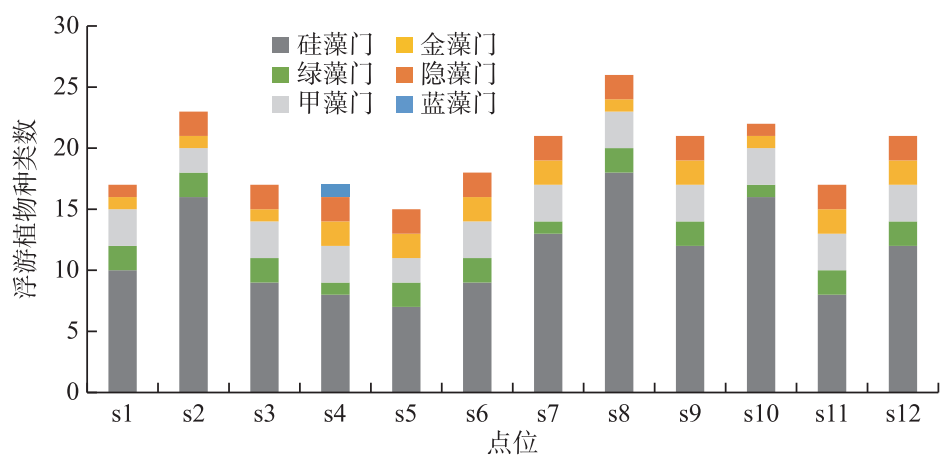

图 2 长海各点位浮游植物种类组成

Fig. 2 Species composition of phytoplankton in each site of Lake Changhai

长海浮游植物丰度在水平变化上差异较大,在 $4.19 \times 10^{5} \sim 9.80 \times 10^{5}$ cells $/ \mathrm{L}$ 之间变化,平均丰度为 $6.98 \times$ $10^{5}$ cells $/ \mathrm{L}$. 其中 $\mathrm{s} 11$ 点位浮游植物丰度最大, 为 $9.80 \times 10^{5}$ cells $/ \mathrm{L}$, 其次是 $\mathrm{s} 4$ 点位, 为 $9.45 \times 10^{5} \mathrm{cells} / \mathrm{L}, \mathrm{s} 1$ 点 位最小, 为 $4.19 \times 10^{5}$ cells/L. 从 s1 点位的人水口到 s12 点位的出水口, 浮游植物丰度逐渐增加, 而沿岸的浮 游植物丰度大于湖心区域( 图 3 ).

生物量的分布规律与丰度略有不同 (图 3), 表现为在水平分布上湖泊中部区域浮游植物生物量高于出 水口和人水口区域. 长海浮游植物各点位在水平分布上生物量变化范围为 $0.19 \sim 0.52 \mathrm{mg} / \mathrm{L}$, 平均生物量为 $0.31 \mathrm{mg} / \mathrm{L}$. 其中 $\mathrm{s} 4$ 点位浮游植物生物量最大, 为 $0.52 \mathrm{mg} / \mathrm{L}$, 其次是 $\mathrm{s} 7$ 点位, 为 $0.46 \mathrm{mg} / \mathrm{L}, \mathrm{s} 1$ 点位最低为 $0.19 \mathrm{mg} / \mathrm{L}$.

\section{2 长海浮游植物的垂直分布}

长海是一个高山深水湖泊, 水温及生物的分层现象明显, 为此我们在湖中心最深的位置 ( $\mathrm{s} 8$ ) 做了浮游 植物垂直分布情况的测定, 各层面的浮游植物种类数和生物量见图 4 6. 

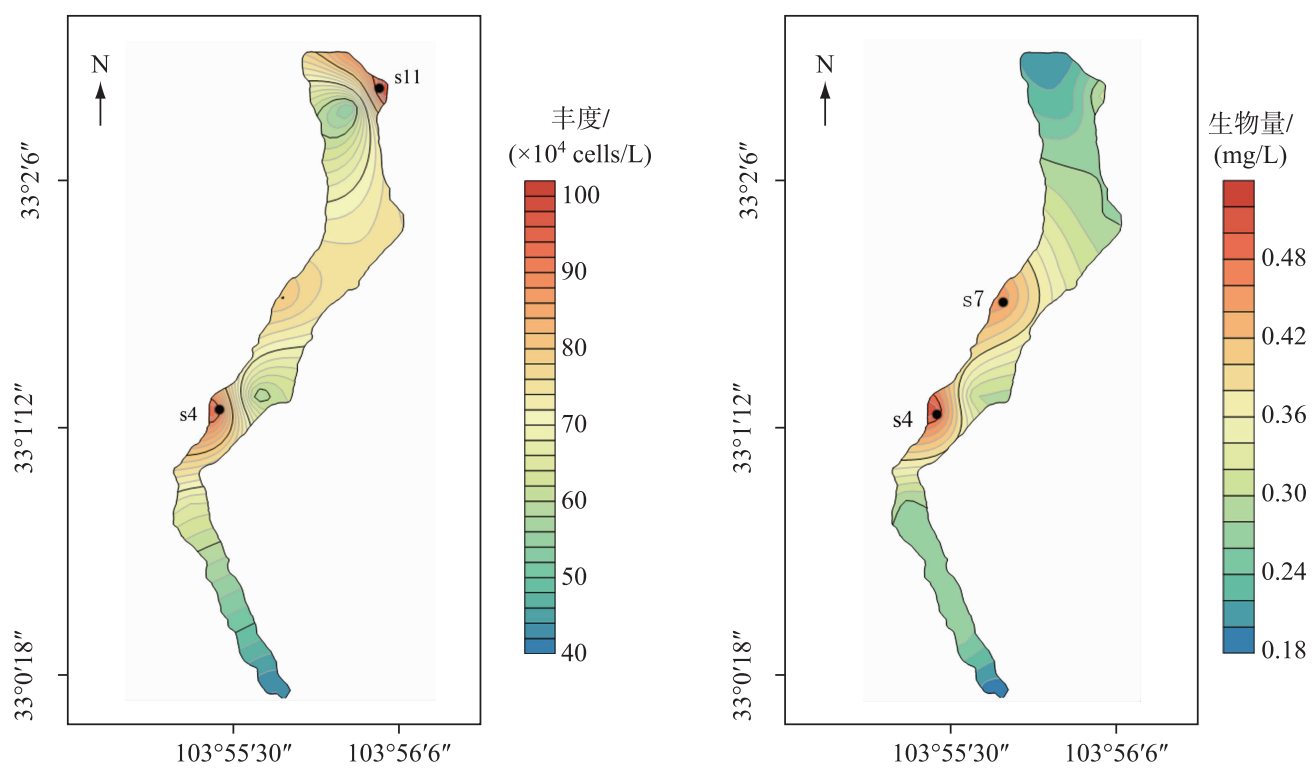

图 3 长海浮游植物丰度和生物量水平分布

Fig. 3 Horizontal distribution of phytoplankon abundance and biomass in Lake Changhai

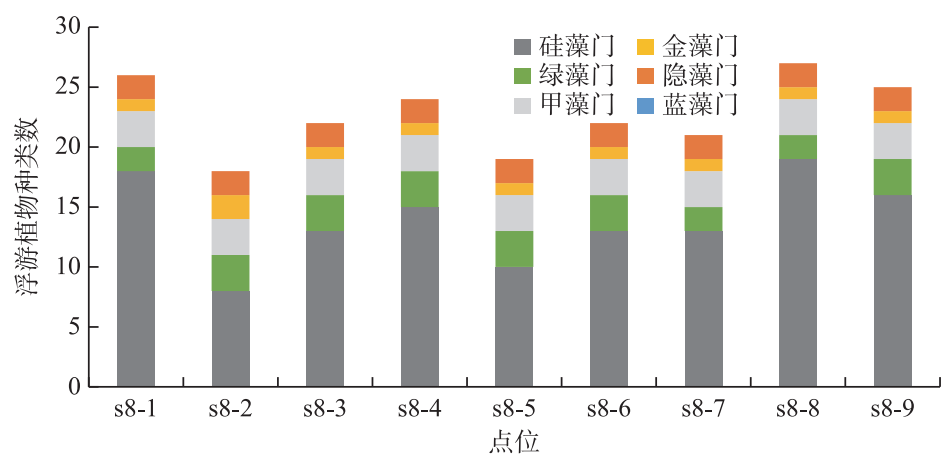

图 4 长海 $\mathrm{s} 8$ 点位浮游植物种类数垂直组成

Fig.4 Vertical composition of phytoplankton species at s8 site in Lake Changhai

从图 4 可以看出, 浮游植物种类数差异不大, 在 $18 \sim 27$ 之间. 从种类组成而言, 硅藻门比例最高, 在 $44.44 \% \sim 70.37 \%$ 之间. 从垂直分布而言, 浮游植物种类数均相差不大, 种类组成均以硅藻门为主.

由图 $5 \mathrm{a}$ 可知, 浮游植物的总丰度从表层 $0.5 \mathrm{~m}$ 至水下 $50 \mathrm{~m}$ 呈现先增加, 在 $20 \mathrm{~m}$ 深处达到最大值 $1.14 \times$ $10^{6} \mathrm{cells} / \mathrm{L}$, 之后随着深度的下降逐渐减少, 并在 $50 \mathrm{~m}$ 处达到最低值 $\left(5.83 \times 10^{5} \mathrm{cell} / \mathrm{s} / \mathrm{L}\right)$. 通过各门浮游植物 丰度的比较可知, 在垂直分布上各点位以硅藻门为主, 其丰度占浮游植物总丰度的 $94.94 \% \sim 97.01 \%$. 变化趋 势同浮游植物总丰度较为一致,在水深 $20 \mathrm{~m}$ 处占比达到最高,在水深 $30 \mathrm{~m}$ 处占比最低.

浮游植物生物量的垂直分布与丰度变化有明显差异 (图 $5 \mathrm{~b}$ ), 在水深 $0.5 \mathrm{~m}$ 处浮游植物生物量达到最 高, 为 $0.34 \mathrm{mg} / \mathrm{L}$, 主要由甲藻门和硅藻门的种类组成. 从水深 $5 \sim 50 \mathrm{~m}$ 呈现先增加后减少的趋势, 在水深 15 $\mathrm{m}$ 和水深 $20 \mathrm{~m}$ 达到峰值, 均为 $0.29 \mathrm{mg} / \mathrm{L}$, 最低值在水深 $50 \mathrm{~m}$ 为 $0.14 \mathrm{mg} / \mathrm{L}$. 通过比较垂直分布各点位各门 浮游植物生物量的变化可知, 硅藻门的变化与总生物量的变化趋于一致, 随着水深增加, 硅藻门生物量先增 加后减少, 在水深 $20 \mathrm{~m}$ 处达到最大值, $0.18 \mathrm{mg} / \mathrm{L}$, 在水深 $50 \mathrm{~m}$ 处达到最小值 $(0.10 \mathrm{mg} / \mathrm{L})$. 而甲藻门在水深 
$0.5 \mathrm{~m}$ 处生物量最大, 为 $0.21 \mathrm{mg} / \mathrm{L}$, 然而在水深 $5 \mathrm{~m}$ 处生物量骤减, 仅有 $0.04 \mathrm{mg} / \mathrm{L}$, 之后随着深度的增加, 同 样呈现先增加后减少的趋势, 在水深 $15 \mathrm{~m}$ 处达到峰值 $0.08 \mathrm{mg} / \mathrm{L}$. 隐藻门的生物量在水深 $10 \sim 30 \mathrm{~m}$ 比其余 深度略高.
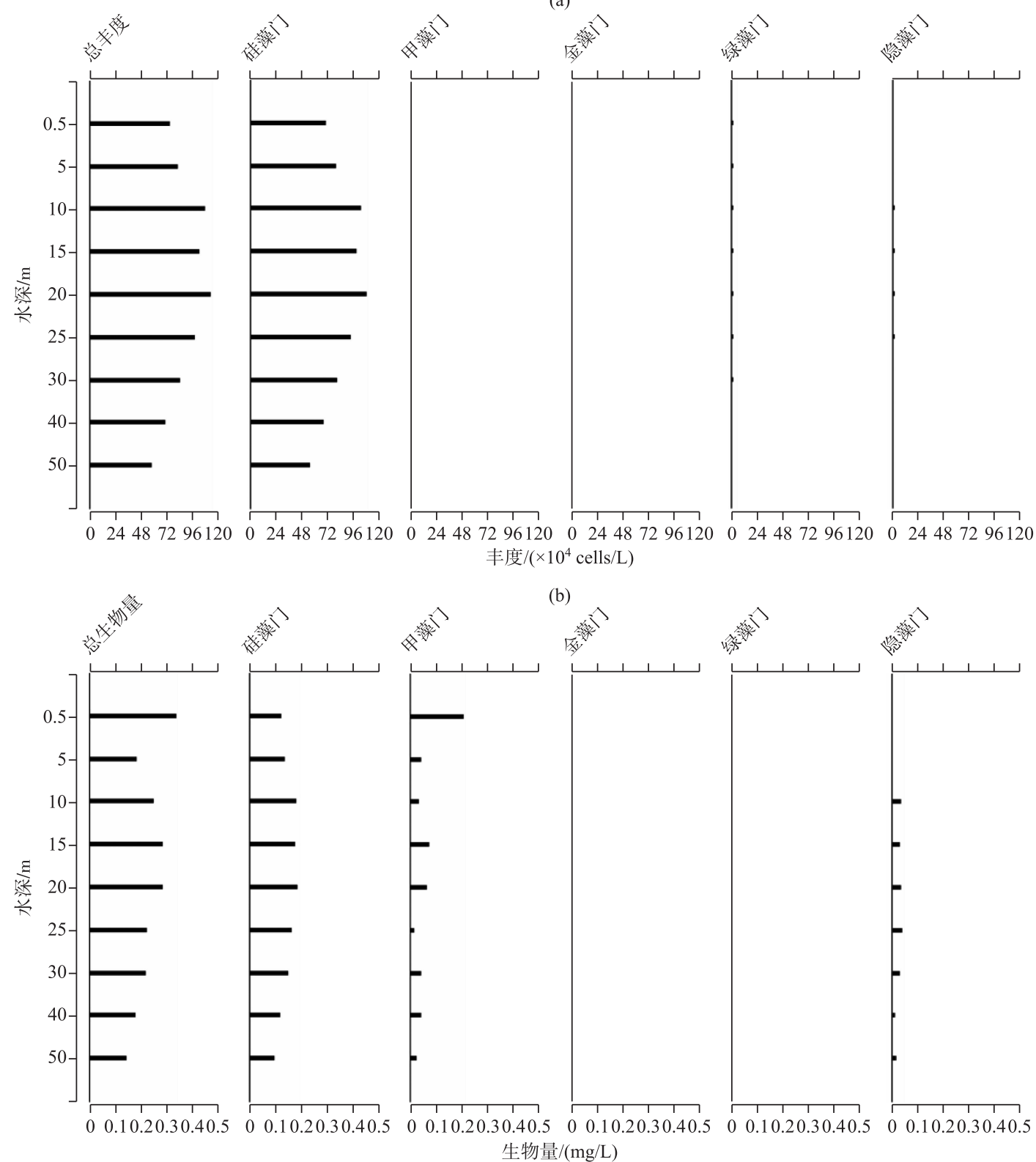

图 5 长海 $\mathrm{s} 8$ 点位浮游植物丰度 $(\mathrm{a})$ 和生物量 $(\mathrm{b})$ 的垂直变化

Fig.5 Vertical variation of phytoplankton abundance(a) and biomass(b) at s8 site in Lake Changhai

\section{3 浮游植物优势种}

将优势度大于 0.02 的定为优势种. 以丰度计算优势种时 (表 1), 长海小环藻 (Cyclotella changhai) 为主 要优势种, 在各点位平均相对丰度为 $77.26 \%$. 在水平分布上, 长海各点位的浮游植物丰度主要由长海小环 
藻组成 (图 6), 各点位相差不大, 其中 s12 点位长海小环藻相对丰度最高为 $84.71 \%, \mathrm{~s} 6$ 点位最低为 $69.85 \%$.

以生物量计算优势种时 (表 2), 飞燕角甲藻 (Ceratium hirundinella) 的优势度最大为 0.50 , 其次为长海小 环藻, 为 0.28 . 由图 7 可知, 飞燕角甲藻和长海小环藻的相对生物量之和占浮游植物总生物量的近 $80 \%$, 其 中飞燕角甲藻的平均相对生物量为 $49 \%$, 长海小环藻的平均相对生物量为 $29.86 \%$. 从相对生物量的水平分 布上来看, 各点生物量的组成相差不大, 均是由飞燕角甲藻和长海小环藻贡献, 其中且除 s12 点位外, 飞燕角 甲藻在各位点的生物量均大于长海小环藻.

表 1 长海浮游植物优势种 (丰度)

Tab. 1 Dominant species of phytoplankton in Lake Changhai (Abundance)

\begin{tabular}{cc}
\hline 优势种 & 优势度 $Y$ \\
\hline 长海小环藻 Cyclotella changhai & 0.76 \\
辐纹琳达藻 Lindavia radiosa & 0.06 \\
克里特小环藻 Cyclotella cretica & 0.05 \\
可辨小环藻 Cyclotella distinguenda & 0.03 \\
\hline
\end{tabular}

表 2 长海浮游植物优势种 (生物量)

Tab.2 Dominant species of phytoplankton in Lake Changhai ( Biomass)

\begin{tabular}{cc}
\hline \multicolumn{1}{c}{ 优势种 } & 优势度 $Y$ \\
\hline 飞燕角甲藻 Ceratium hirundinella & 0.50 \\
长海小环藻 Cyclotella changhai & 0.28 \\
辐纹琳达藻 Lindavia radiosa & 0.03 \\
克里特小环藻 Cyclotella cretica & 0.03 \\
\hline
\end{tabular}

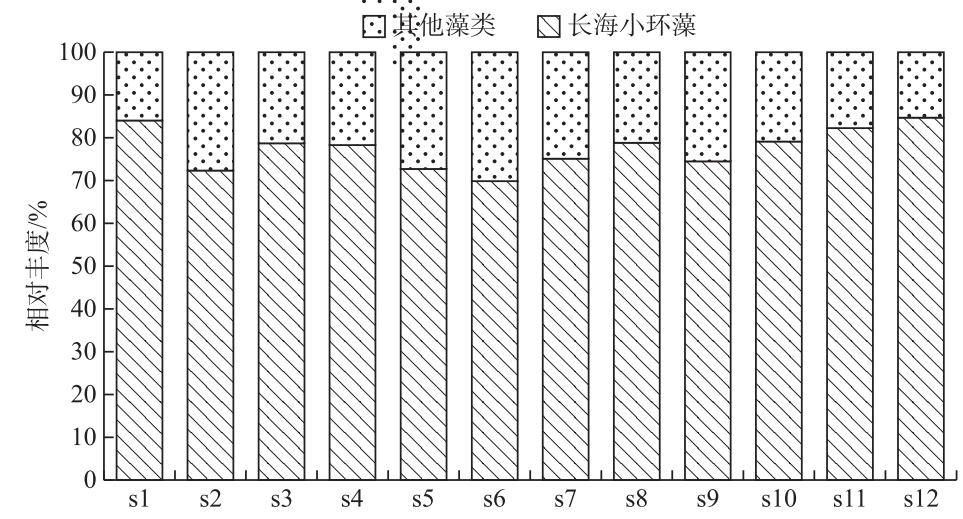

图 6 长海小环藻和其他藻类相对丰度的水平分布

Fig.6 Horizontal distribution of relative abundance of Cyclotella changhai and other algae

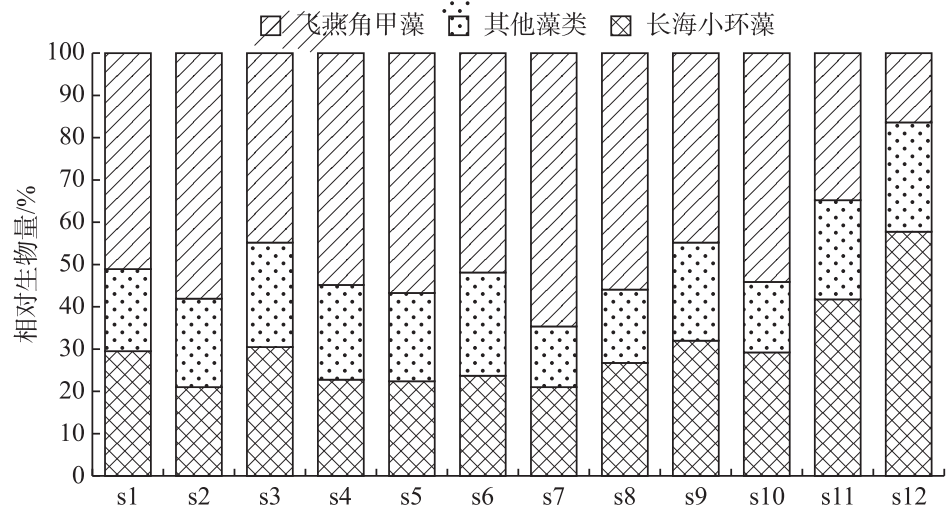

图 7 飞燕角甲藻、长海小环藻和其他藻类相对生物量的水平分布

Fig.7 Horizontal distribution of relative biomass of Ceratium hirundinella, Cyclotella changhai and other algae 
优势种的差异主要是由飞燕角甲藻体积系数较大数造成, 虽然飞燕角甲藻在各点位的平均丰度较低, 其丰度大小不到长海小环藻的 $1 / 100$, 但是飞燕角甲藻的体积系数大约是长海小环藻的 313 倍. 故在计算长 海浮游植物优势种的时候考虑了丰度和生物量两种参数.

\section{4 浮游植物多样性及水质评价}

长海水质评价的方法包括理化参数评价和生物评价两种方法.

采用单项的水体理化因子对水质状况进行评价, 包括 TN、TP 和 DO. 长海水平各点位水体理化数据见 表 3 , TN 浓度范围为 $0.21 \sim 0.66 \mathrm{mg} / \mathrm{L}$, 平均值为 $0.40 \mathrm{mg} / \mathrm{L} ; \mathrm{TP}$ 浓度范围为 $0.01 \sim 0.03 \mathrm{mg} / \mathrm{L}$; DO 浓度范围为 7.36 9.82 mg/L, 平均值 $8.68 \mathrm{mg} / \mathrm{L}$. 根据地表水环境质量标准 ${ }^{[39]}$ 进行水质状况评价可知, 通过 TN 进行水质 评价, 大部分点位和平均值均显示长海水体应属于 II 类水体, $\mathrm{s} 8$ 和 $\mathrm{s} 10$ 点位偏向于 III 类水体; 通过 TP 进行 水质评价, 大部分点位和平均值均显示长海水体应属于 I 类水体, $\mathrm{s} 2$ 点位偏向于 II 类水体; 通过 DO 进行水 质评价, 大部分点位和平均值均显示长海水体应属于 I 类水体, $\mathrm{s} 1$ 和 $\mathrm{s} 7$ 点位偏向于 II 类水体 (表 4).

表 3 长海各点位水体理化数据

Tab.3 Physical and chemical data of each site in Lake Changhai

\begin{tabular}{cccccccc}
\hline 点位 & $\begin{array}{c}\text { 水深/ } \\
\mathrm{m}\end{array}$ & $\begin{array}{c}\text { 水温/ } \\
{ }^{\mathrm{C}}\end{array}$ & $\begin{array}{c}\mathrm{DO} / \\
(\mathrm{mg} / \mathrm{L})\end{array}$ & $\begin{array}{c}\mathrm{TDS} / \\
(\mathrm{mg} / \mathrm{L})\end{array}$ & $\mathrm{pH}$ & $\begin{array}{c}\mathrm{TP} / \\
(\mathrm{mg} / \mathrm{L})\end{array}$ & $\begin{array}{c}\mathrm{TN} / \\
(\mathrm{mg} / \mathrm{L})\end{array}$ \\
\hline $\mathrm{s} 1$ & 2.5 & 15.5 & 7.36 & 161.85 & 8.29 & 0.03 & 0.31 \\
$\mathrm{~s} 2$ & 14.5 & 14.9 & 8.36 & 161.20 & 8.27 & $<0.01$ & 0.26 \\
$\mathrm{~s} 3$ & 27.3 & 14.9 & 9.46 & 161.20 & 8.32 & $<0.01$ & 0.45 \\
$\mathrm{~s} 4$ & 10 & 16.1 & 9.21 & 162.50 & 8.76 & 0.01 & 0.43 \\
$\mathrm{~s} 5$ & 64 & 15.1 & 9.38 & 161.85 & 8.28 & $<0.01$ & 0.33 \\
$\mathrm{~s} 6$ & 27 & 15.6 & 8.45 & 163.15 & 8.28 & $<0.01$ & 0.21 \\
$\mathrm{~s} 7$ & 12 & 15.3 & 7.37 & 161.85 & 8.30 & $<0.01$ & 0.43 \\
$\mathrm{~s} 8$ & 80 & 14.9 & 8.55 & 161.85 & 8.27 & $<0.01$ & 0.58 \\
$\mathrm{~s} 9$ & 62 & 15.1 & 9.82 & 161.85 & 8.34 & $<0.01$ & 0.39 \\
$\mathrm{~s} 10$ & 56 & 14.7 & 9.09 & 161.85 & 8.45 & $<0.01$ & 0.66 \\
$\mathrm{~s} 11$ & 18.5 & 15.1 & 7.63 & 161.85 & 8.33 & $<0.01$ & 0.46 \\
$\mathrm{~s} 12$ & 20.7 & 14.4 & 9.53 & 162.50 & 8.52 & 0.01 & 0.28 \\
\hline
\end{tabular}

表 4 长海水体理化因子水质评价

Tab.4 Water quality evaluation of physical and chemical factors in Lake Changhai

\begin{tabular}{|c|c|c|c|c|c|c|c|c|c|c|c|c|c|}
\hline 水体评价因子 & s1 & $\mathrm{s} 2$ & s3 & s4 & s5 & s6 & s7 & s8 & s9 & s10 & s11 & $\mathrm{s} 12$ & 平均 \\
\hline TN 评价 & II 类 & II 类 & II 类 & III类 & II 类 & II 类 & II 类 & II 类 & II 类 & II 类 & II 类 & III类 & II 类 \\
\hline $\mathrm{TP}$ 评价 & II 类 & I 类 & I 类 & I 类 & I 类 & I 类 & I 类 & I 类 & I 类 & I 类 & I 类 & I 类 & I类 \\
\hline DO 评价 & II 类 & I 类 & I 类 & I 类 & I 类 & I 类 & II 类 & I 类 & I 类 & I 类 & I 类 & I 类 & I 类 \\
\hline
\end{tabular}

长海水质的生物参数评价主要包括浮游植物丰度、生物量、优势种和多样性指数.

长海浮游植物丰度为 $4.19 \times 10^{5} \sim 9.80 \times 10^{5} \mathrm{cells} / \mathrm{L}$, 平均丰度为 $6.98 \times 10^{5} \mathrm{cells} / \mathrm{L}$, 属于中营养型湖泊; 长 海浮游植物生物量为 $0.19 \sim 0.52 \mathrm{mg} / \mathrm{L}$, 平均生物量为 $0.31 \mathrm{mg} / \mathrm{L}$, 属于贫营养型湖泊.

通过与近似种 Cyclotella comensis、Cyclotella pseudocomensis 和 Cyclotella costei ${ }^{[40]}$ 的生境和现场、后期理化 监测数据比较发现, 长海小环藻与上述形态近似种均属于生长在贫一中营养环境的浮游硅藻; 其他优势种 Cyclotella distinguenda 隶属小环藻属, 世界广泛分布种, 浮游硅藻主要生长在碱性水体; Cyclotella cretica 隶属 小环藻属, 浮游硅藻, 目前只在希腊克里特岛发现; Lindavia radiosa (浮游硅藻), 多出现在贫一中营养的高山 湖泊; 飞燕角甲藻, 甲藻门浮游植物, 浮游藻类, 广泛分布种类, 多出现在中营养且静止的水体 ${ }^{[41]}$.

浮游植物 Shannon-Wiener 多样性指数 $H^{\prime}$ 值范围为 $1.11 \sim 1.76$, 平均值为 1.44 , 属于重污染; Margalef 多样 性指数 $d$ 值范围为 $1.06 \sim 1.85$, 平均值为 1.38 , 属于 $\alpha$-中污一重污染; Pielou 均匀度指数 $e$ 值范围为 $0.06 \sim$ 
0.09 , 平均值为 0.07 , 属于重污染 (图 8).

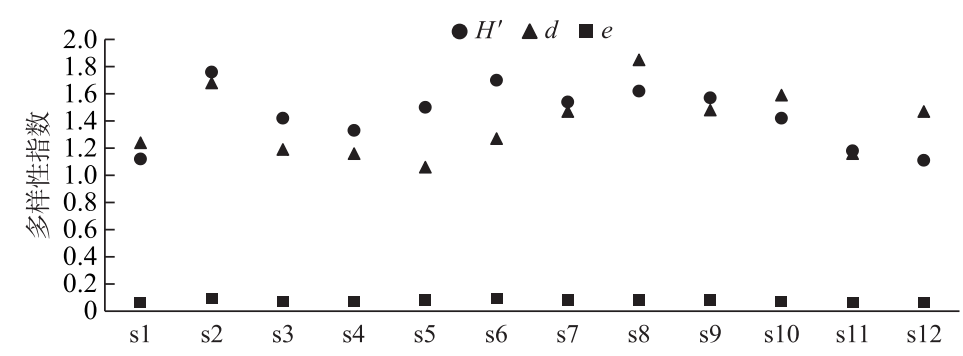

图 8 长海浮游植物多样性指数分布

Fig. 8 Distribution of diversity indexes of phytoplankton in Lake Changhai

\section{3 讨论}

\section{1 长海浮游植物群落水平分布特征}

长海的浮游植物种类数只有 63 种, 与洱海 192 种 ${ }^{[42]}$ 、沾沽湖 146 种 $^{[43]}$, 抚仙湖 151 种 ${ }^{[44]}$ 、滇池 97 种 ${ }^{[45]}$ 、长白山圆池 92 种 ${ }^{[46]}$ 相比较少, 与意大利伊塞奥湖 59 种 ${ }^{[47]}$ 相差不大, 可能与长海的高海拔、湖泊面积 小、水深较深有关. 在夏季的高山湖泊中, 当温度和光照达到了非限制水平的时候, 浮游植物的生长受到营 养水平的限制 ${ }^{[48-49]}$. 在贫一中营养型湖泊中, 硅藻通常在浮游植物总丰度中占有最高的比例 ${ }^{[50]}$. 在阿尔卑斯 山 48 个湖泊中, 硅藻门占了总生物量的 $50 \%$ 以上 ${ }^{[51]}$. 长海的浮游植物种类组成也是以硅藻门为主. 长海浮 游植物丰度主要是受到长海小环藻丰度变化的影响, 主要是因为长海水温和营养水平较低, 按地表水标准 属于 I II 类水体, 而长海小环藻相比于小环藻属的其他种类体积更小 $(7 \sim 11 \mu \mathrm{m})$, 有较高的体积和面积 比, 能够更好地适应低温低营养环境. Garibaldi 等 ${ }^{[47]}$ 在 $1998-2000$ 年间对伊塞奥湖浮游植物群落调查中也 发现, 小环藻在夏季优先生长, 这得益于其体积小, 沉降速率较低, 与其他大型硅藻相比有较高的竞争二氧 化硅的能力. 长海浮游植物的生物量由长海小环藻和飞燕角甲藻的共同影响, 长海小环藻丰度较高而飞燕 角甲藻的细胞体积相对较大.

因为长海处于则查洼沟的中部, 只有一处面积较小的观景走廊, 游客人流量和人为活动较小, 是一个受 人为干扰少、换水周期较长的高山冷水湖泊, 所以其浮游植物丰度和生物量主要是由湖泊自身结构影响, 受 到光照、温度、深度和水体流动性的影响, 从而造成了水平分布上浮游植物丰度和生物量的变化 ${ }^{[48]}$. 浮游植 物总丰度和生物量均显示沿人水口到出水口的方向逐渐增多, 而靠近人水口的区域水体摚动性较大, 不如 近湖心区水体稳定, 更适合长海小环藻和飞燕角甲藻生长; 部分沿岸点位如 $\mathrm{s} 4$ 的浮游植物丰度和生物量较 大, 主要因为靠近沿岸区, 深度较浅, 更容易受光和到来自沿岸区营养盐的影响 ${ }^{[52]}$.

\section{2 长海浮游植物群落垂直分布特征}

浮游植物的垂直分布的差异主要是因为沉降 (没有运动能力且丰度比水大的藻类, 例如硅藻) 、漂浮 (例 如蓝藻的伪空胞)、鞭毛藻类的迁移, 而水体透明度、光强度、水流、水体摚动和水温等理化因素也影响了浮 游植物的垂直分布. 贡献了 $80 \%$ 浮游植物丰度的长海小环藻是一种无鞭毛藻且密度大于水的藻类, 随着水 温的升高沉降速度加快. 但长海海拔高近 $3000 \mathrm{~m}$, 光强度较大, 水体本身透明度高, 表层高强度的光照和较 高的水温会抑制长海小环藻的繁殖, 随着深度增加, 光强度和水温降低, 水深 $15 \mathrm{~m}$ 是长海小环藻最适的生 长区域, 而随着深度的下降生长率又逐渐降低 ${ }^{[48]}$. 故浮游植物丰度变化呈现先增加后减小的趋势. 潘继 征 ${ }^{[53]}$ 等对抗仙湖的研究也表明, 在深水湖泊, 水体混合交换弱, 会形成浮游植物上下分布明显差异, 浮游植 物主要分布在 $0 \sim 30 \mathrm{~m}$ 水层,而且随着水深增加呈现递减趋势.

长海浮游植物生物量沿垂直方向的变化主要受到飞燕角甲藻生物量和长海小环藻生物量的共同影响. 飞燕角甲藻具有鞭毛, 有自主迁移的能力, 对水温和光强的要求比硅藻门要高, 所以在水深 $0.5 \mathrm{~m}$ 时, 飞燕角 甲藻的生物量达到最大值, 随着水深增加, 光照和水温降低, 飞燕角甲藻的生物量也逐渐减少. 而小环藻生 
物量在垂直方向上呈现先增大后减小的趋势, 并在 $15 \sim 20 \mathrm{~m}$ 时达到其最大值. 因此可以说明光照和水温影 响着长海浮游植物群落的组成、丰度和生物量的变化.

\section{3 长海浮游植物多样性及水质状况}

一般来讲, 多样性指数越高, 群落结构越稳定, 水质状况也越好 ${ }^{[21]}$. 但是长海的多样性指数和均匀度指 数的评价显示水体呈重污染水平, 而单因素理化指标显示长海水体属于 I II 类水体, 与生物评价中的优势 种评价、生物量评价和丰度评价中的中一贫营养型水体结果是一致的, 也与长海水环境现状相一致. 不同的 水质评价指标显示出不同, 甚至矛盾的评价结果 ${ }^{[54]}$. 而在抚仙湖等高山湖泊中, 多样性评价能够较好地评 价水体状况. 如吉正元等 ${ }^{[55]}$ 使用 Shannon-Wiener 多样性指数、Pielou 均匀度和细胞密度这 3 项指标对抗仙 湖水质进行了评价, 显示抚仙湖水质为轻污染、贫中营养类型. 张俊芳等 ${ }^{[56]}$ 综合 Shannon-Wiener 多样性指 数、Pielou 均匀度、Margalef 多样性指数、Simpson 多样性指数对山西宁武亚高山湖评价水体状况显示为轻污 染. 长海浮游植物多样性指数评价显示为重污染, 是因为长海的水温较低, 平均水温在 $15^{\circ} \mathrm{C}$, 水体滞留时间 较长, 水域面积较大, 人为干扰少, 使得长海小环藻和飞燕角甲藻在丰度和生物量上占据了绝对优势, 从而 减少了多样性和均匀度. 在使用多样性判断水质状况时, 应该了解影响该水体生物多样性的因素, 然后再综 合环境因子等其他指标分析和比较 ${ }^{[77-58]}$. 因此, 多样性评价不适合长海的水质评价, 而应该参考水体理化因 子评价与生物评价中的指示种评价以及生物量及丰度的评价结果. 虽然长海水质状况目前较好, 但仍需对 其加强重视, 强化监管力度, 控制游客数量, 减少人为干扰, 最大程度减少旅游开发对于环境的不利影响, 实 现生态旅游的可持续发展.

\section{4 结论}

1) 长海共发现浮游植物 6 门 38 属 63 种, 以硅藻门为主. 浮游植物平均丰度为 $6.98 \times 10^{5} \mathrm{cell} / \mathrm{s} / \mathrm{L}$, 平均生 物量为 $0.31 \mathrm{mg} / \mathrm{L}$.

2) 在垂直分布上, 从表层 $0.5 \mathrm{~m}$ 至水下 $50 \mathrm{~m}$ 浮游植物丰度呈现先增加后减少的趋势, 在 $20 \mathrm{~m}$ 水深处达 到最大值. 生物量在 $0.5 \mathrm{~m}$ 水深处最高, 主要由甲藻门和硅藻门组成, 之后随着深度先增加后减少.

3) 长海的主要优势种是长海小环藻和飞燕角甲藻. 长海小环藻数量较多, 飞燕角甲藻生物量较大.

4) 长海浮游植物多样性指数较低, 与水体现状和优势种评价结果不一致, 说明长海的水质评价应该参 考水体理化因子评价与生物评价中的指示种评价以及生物量及丰度的评价结果. 综合各种评价标准, 可以 得出, 长海属于 I II 类水体,处于贫一中营养水平.

致谢: 感谢九寨沟国家级自然保护区管理局在采样中给予的帮助与支持, 感谢美国波特兰州立大学潘仰东 教授在研究中给予的意见和建议.

\section{5 参考文献}

[ 1 ] Pan YD, Deng GP, Wang LZ et al. Effects of in situ phosphorus enrichment on the benthos in a subalpine Karst stream and implications for bioassessment in nature reserves. Ecological Indicators, 2017, 73: 274-283. DOI: 10.1016/j.ecolind. 2016.09.055.

[ 2 ] Wang J, Bao WK, He BH et al. Effect of tourism on nitrogen and phosphorus loss in surface runoff in Jiuzhaigou world nature heritage reserve. Ecology and Environment, 2006, 15(2):284-288. [王晶, 包维楷, 何丙辉等. 旅游活动对九寨 沟地表径流氮磷流失的影响研究. 生态环境, 2006, 15(2): 284-288.]

[ 3 ] Liu SY, Zhang XP, Zeng ZY eds. Biodiversity of the Jiuzhaigou National Nature Reserve. Chengdu: Sichuan Technological Press, 2007. [刘少英, 章小平, 曾宗永. 九寨沟自然保护区的生物多样性. 成都: 四川科学技术出版社, 2007.]

[ 4] Deng GP ed. Tourism geosciences landscape formation and protection of Jiuzhaigou Nature Reserve. Beijing: Science Press, 2012. [邓贵平. 九寨沟旅游地学景观成因与保护. 北京: 科学出版社, 2012.]

[ 5 ] Schmidt RP. Climate changes and anthropogenic impacts as causes for $\mathrm{pH}$ fluctuation in remote alpine lakes. Documenta Ist Ital Idrobiol, 1992, 32: 31-57.

[ 6 ] Psenner R. Alpine waters in the interplay of global change: complex links-simple effects? Global environmental change in alpine regions, Edward Elgar Publishing, 2002: 271. 
[ 7 ] Hofer R, Lackner R, Kargl J et al. Organochlorine and metal accumulation in fish (Phoxinus phoxinus) along a northsouth transect in the Alps. Water, Air, and Soil Pollution, 2001, 125(1) : 189-200. DOI: 10.1023/A:1005272308236.

[ 8 ] Tolotti M, Manca M, Angeli N et al. Phytoplankton and zooplankton associations in a set of alpine high altitude lakes: Geographic distribution and ecology. Hydrobiologia, 2006, 562 (1) : 99-122. DOI: 10.1007/s10750-005-1807-8.

[ 9 ] Zhu WJ, Pang WT, You QM et al. Phytoplankton community structure and the evaluation of water quality in spring, Huaihe River Basin. J Lake Sci, 2017, 29(3) : 637-645. DOI: 10.18307/2017.0312. [朱为菊, 庞婉婷, 尤庆敏等. 淮河 流域春季浮游植物群落结构特征及其水质评价. 湖泊科学, 2017, 29(3) : 637-645.]

[10] Pero P. Ricerche e studi sui laghi valtellinesi. Nova Notarisia, 1893, 4: 47-133.

[11] Zschokke F. Die Tierwelt der Juraseen. Revue Suisse Zool, 1894, 2: 349-376.

[12] Pesta O. Hochgebirgsseen und ihre Fauna I Beitrag. Verh Zool Bot Ges Wien, 1912, 62: 158-171.

[13] De Marchi M. Streblocerus serricaudatus nel Trentino. Atti Soc Sc Nat Milano, 1913, 51: 107-216.

[14] Monti R. Un nuovo modo di migrazione dello zoop- lancton fin qui sconosciuto. Rend R Ist Lomb Soc Lett, 1905, 38 : 122-132.

[15] Monti R. Le migrazioni attive e passive degli organismi di alta montagna. Rend R Ist Lomb Soc Lett, 1908, 38: 899-912.

[16] Pechlaner R. Plancton production in natural lakes and hydro-electric water-basins in the alpine region of the Austrian Alps. SIL Proceedings, 1922-2010, 1964, 15(1) : 375-383. DOI: 10.1080/03680770.1962.11895550.

[17] Tilzer M, Schwarz K, Seasonal and vertical patterns of phytoplankton light adaptation in a high mountain lake. Archiv fir Hydrobiologie, 1976, 44: 488-504.

[18] Tolotti M. Phytoplankton and littoral epilithic diatoms in high mountain lakes of the Adamello-Brenta Regional Park ( Trentino, Italy) and their relation to trophic status and acidification risk. Journal of Limnology, 2001, 60(2). DOI: 10. 4081/jlimnol.2001.1.171.

[19] Rodhe W, Hobbie JE, Wright RT. Phototrophy and heterotrophy in high mountain lakes. SIL Proceedings, 1922-2010, 1966, 16(1) : 302-313. DOI: 10.1080/03680770.1965.11895699.

[20] Porter KG. Phagotrophic phytoflagellates in microbial food webs. Hydrobiologia, 1988, 159 ( 1 ): 89-97. DOI: 10. 1007/bf00007370.

[21] Gervais F. Light-dependent growth, dark survival, and glucose uptake bycryptophytes isolated from a freshwater chemocline1. Journal of Phycology, 1997, 33(1) : 18-25. DOI: 10.1111/j.0022-3646.1997.00018.x.

[22] Jsaksson A. Phagotrophic phytoplangellates in lakes-A literature review. Arch Hydrobiol Spec Issues Advanc Limnol, 1998, 51: 63-90.

[23] Jacquemin C, Bertrand C, Oursel B et al. Growth rate of alpine phytoplankton assemblages from contrasting watersheds and N-deposition regimes exposed to nitrogen and phosphorus enrichments. Freshwater Biology, 2018, 63(10) : 1326-1339. DOI : $10.1111 /$ fwb. 13160 .

[24] de Senerpont DLN, Elser JJ, Gsell AS et al. Plankton dynamics under different climatic conditions in space and time. Freshwater Biology, 2013, 58(3) : 463-482. DOI: 10.1111/fwb.12053.

[25] Schindler DE, Knapp RA, Leavitt PR. Alteration of nutrient cycles and algal production resulting from fish introductions into Mountain lakes. Ecosystems, 2001, 4(4) : 308-321. DOI: 10.1007/s10021-001-0013-4.

[26] Winder M, Sommer U. Phytoplankton response to a changing climate. Hydrobiologia, 2012, 698 ( 1) : 5-16. DOI: 10. 1007/s10750-012-1149-2.

[27] Yun BC, Jiang EL, Bao XX et al. An investigation on the algae of Tian Chi lake of mountain Baitou. Songliao Journal, $1992,13(4)$ : 22-25. [云宝琛, 姜恩来, 暴学祥等. 长白山天池藻类的调查. 松辽学刊: 自然科学版, 1992,13 (4) : 22-25.

[28] Ma XD, Chen YN, Huang S et al. Community structure and diversity of phytoplankton in Lake Chaiwopu. Journal of Arid Land Resources and Environment, 2009, 23(4) : 191-195. [马晓东, 陈亚宁, 黄适等. 新疆柴窝堡湖浮游植物群落结 构及其多样性. 干旱区资源与环境, 2009, 23(4) : 191-195.]

[29] Zhang ZS, Huang XF eds. The methods for freshwater plankton research. Beijing: Science Press, 1991. [章宗涉, 黄祥 飞. 淡水浮游生物研究方法. 北京: 科学出版社, 1991.]

[30] Zhao AP, Liu FY, Wu B et al. Phytoplankton from the Dianshan Lake in Shanghai. Journal of Shanghai Normal University: Natural Sciences, 2005, 34(4) : 70-76. [赵爱萍, 刘福影, 吴波等. 上海淀山湖的浮游植物. 上海师范大学学 
报: 自然科学版, 2005, 34(4): 70-76.]

[31] Bi LJ, Hu ZY eds. Floraalgarum sinicarum aquae dulcis Tomus VIII Chlorococcales( I ). Beijing: Science Press, 2004. [ 毕列爵, 胡征宇. 中国淡水藻志第八卷绿球藻目 (上). 北京: 科学出版社, 2004 . ]

[32] Shi ZX ed. Flora algarum sinicarum aquae dulcis Tomus VI Euglenophyta. Beijing: Science Press, 1999. [施之新. 中国 淡水藻志第六卷裸藻门. 北京: 科学出版社, 1999.]

[33] Liu GX, Hu ZY eds. Floraalgarum sinicarum aquae dulcis Tomus XV Chlorococcales( II ). Beijing: Science Press, 2012. [刘国祥，胡征宇. 中国淡水藻志第十五卷绿球藻目 (下). 北京: 科学出版社, 2012.]

[34] Hu HJ ed. Flora algarum sinicarum aquae dulcis Tomus XX Chlorophyta Chlorophyceae Order Volvocales( II ). Beijing: Science Press, 2015. [胡鸿钧. 中国淡水藻志第二十卷绿藻门绿藻纲团藻目 ( II ) 衣藻属. 北京: 科学出版 社, 2015.]

[35] Wei YX ed. Floraalgarum sinicarum aquae dulcis Tomus VII Chlorophyta Zygnematales Mesotaeniaceae Desmidiales Desmidiacead SectioI. Beijing: Science Press, 2003. [魏印心. 中国淡水藻志第七卷绿藻门双星藻目中带鼓藻科鼓藻目 鼓藻科第 1 册. 北京: 科学出版社, 2003.]

[36] Zhu HZ, Chen JY eds. Bacillariophyta of the Xizang Plateau. Beijing: Science Press, 2000. [朱惠忠, 陈嘉佑. 中国西 藏硅藻. 北京: 科学出版社, 2000.]

[37] Jin XC,Tu QY eds. The standard methods in lake eutrophication investigation ( second edition). Beijing: China Environmental Science Press, 1990. [金相灿, 屠清瑛. 湖泊富营养化调查规范 (第二版). 北京: 中国环境科学出版 社, 1990.]

[38 ] Shen YF, Zhang ZS, Gong XJ et al eds. Modern biomonitoring techniques using freshwater microbiota. Beijing: China Architecture \& Building Press, 1990. [沈蕴芬, 章宗涉, 龚循矩等. 微型生物监测新技术. 北京: 中国建筑工业出版 社, 1990.]

[39] Peng JX ed. Water quality eutrophication and prevention. Beijing: China Environmental Science Press, 1988. [彭近新. 水质富营养化与防治. 北京: 中国环境科学出版社, 1988. $]$

[40] Krammer K, Lange-Bertalot H eds. Bacillariophyceae. 1. Teil: Naviculaceae in süsswasserflora von Mitteleuropa. Band 2/ 1. Heidelberg: Spektrum Akademischer Verlag, 1986.

[41] Hu HJ, Wei YX eds. The freshwater algae of China. Beijing: Science Press, 2006. [胡鸿钧, 魏印心. 中国淡水藻类. 北京: 科学出版社, 2006.]

[42] Zhang SW, Dong YX. A review of study on phytoplankton in Dianchi lake, Erhai lake, and Lugu lake. Environmental Science Survey, 2014, 33(4) : 13-18, 44. [张石文, 董云仙. 滇池、洱海、泸沽湖浮游植物研究综述. 环境科学导刊, $2014,33(4): 13-18,44$.

[43] Dong YX, Tan ZW, Guo YY. The preliminary study on phytoplankton in Lugu lake[Dissertation]. Journal of Hydroecolo$g y, 2012,33(3)$ : 46-52. DOI : 10.15928/j.1674-3075.2012.03.005. [董云仙, 谭志卫, 郭艳英. 泸沽湖浮游植物的 初步研究 [学位论文]. 水生态学杂志, 2012, 33(3) : 46-52.]

[44] Jiang YN. Spatio-temporal distribution and environmental drivers of phytoplankton community and diversity in Fuxian lake [Dissertation]. Kunming: Yunnan Normal University, 2017. [蒋伊能. 抚仙湖浮游植物群落与多样性的时空变化特 征及其影响因子研究 [学位论文]. 昆明: 云南师范大学, 2017.]

[45] Dai GY, Li J, Li L et al. The spatio-temporal pattern of phytoplankton in the north basin of lake Dianchi and related environmental factors. Acta Hydrobiologica Sinica, 2012, 36(5) : 946-956. DOI: 10.3724/SP.J.1035.2012.00946. [代龚圆， 李杰, 李林等. 滇池北部湖区浮游植物时空格局及相关环境因子. 水生生物学报, 2012, 36(5) : 946-956.]

[46] Zou JY, Liu H. Study on status of plankton in summer of Yuanchi in Changbai mountain. Journal of Anhui Agricultural Sciences, 2013, 41(25) : 10450-10452. [邹继渘, 刘辉. 长白山圆池夏季浮游生物现状研究. 安徽农业科学, 2013, 41 (25) : 10450-10452.]

[47] Garibaldi L, Anzani A, Marieni A et al. Studies on the phytoplankton of the deep subalpine Lake Iseo. Journal of Limnolo$g y, 2003,62(2)$ : 177. DOI: 10.4081/jlimnol.2003.177.

[48] Bergstrom AK, Jansson M, Drakare S et al. Occurrence of mixotrophic flagellates in relation to bacterioplankton production, light regime and availability of inorganic nutrients in unproductive lakes with differing humic contents. Freshwater Biology, 2003, 48(5) : 868-877. DOI: 10.1046/j.1365-2427.2003.01061.x.

[49] Lewis W. Global primary production of lakes: 19th Baldi Memorial Lecture. Inland Waters, 2011, 1(1) : 1-28. DOI: 10. 
5268/iw-1.1.384.

[50］ Gu BH ed. Limnology inland water ecosystems. Beijing: Higher Education Press, 2011. [古滨河. 湖沼学一一内陆水生 态系统. 北京: 高等教育出版社, 2011.]

[51] Sommaruga R. The role of solar UV radiation in the ecology of alpine lakes. Journal of Photochemistry and Photobiology B : Biology, 2001, 62(1/2) : 35-42. DOI: 10.1016/s1011-1344(01)00154-3.

[52] Edmondson WT. The relation of photosynthesis by phytoplankton to light in lakes. Ecology, 1956, 37(1) : 161-174. DOI: $10.2307 / 1929679$.

[53] Pan JZ, Xiong F, Li WC et al. Structure, distribution and its impact factors of phytoplankton community in Fuxian Lake. Acta Ecologica Sinica, 2009, 29(10) : 5376-5385. [潘继征, 熊飞, 李文朝等. 抚仙湖浮游植物群落结构、分布及其 影响因子. 生态学报, 2009, 29(10): 5376-5385.]

[54] Qin JJ, Wang Y. Application and evaluation of phytoplankton diversity indexes. Journal of Shenyang Normal University: Natural Science Edition, 2014, 32(4) : 502-505. [秦娇娇, 王艳. 浮游植物多样性指数的应用及评价. 沈阳师范大 学学报: 自然科学版, 2014, 32(4): 502-505.]

[55] Ji ZY, Liu SJ, Shi YF et al. Annual variation of phytoplankton community structure in Fuxian Lake and bioassessment of its water quality. Transactions of Oceanology and Limnology, 2019, (3) : 78-86. [吉正元, 刘绍俊, 施艳峰等. 抚仙湖 浮游植物群落结构周年变化及水质生物评价. 海洋湖沼通报, 2019, (3) : 78-86.]

[56] Zhang JF, Feng J, Xie SL et al. Characteristics of phytoplankton community structures in Ningwu subalpine lakes, Shanxi Province. J Lake Sci, 2012, 24(1) : 117-122. DOI: 10.18307/2012.0116. [张俊芳, 冯佳, 谢树莲等. 山西宁武亚高 山湖群浮游植物群落结构特征. 湖泊科学, 2012, 24(1): 117-122.]

[57] Sun JL, Dong ZQ, Qu LY et al. Preliminary investigation and index evaluation of phytoplankton in Wanfeng lake in Guizhou Province. Journal of Anhui Agricultural Sciences, 2008, 36(23) : 10096-10097. [孙嘉龙, 董泽琴, 翟丽雅等. 贵州万峰湖浮游植物的调查及其指数评价. 安徽农业科学, 2008, 36(23) : 10096-10097.]

[58] Zhang LP. Analysis of algae in Chaohu Lake. Journal of Biology, 2007, 24(6) : 53-72. [张良璞. 巢湖藻类群落多样性 分析. 生物学杂志, 2007, 24(6): 53-72.] 